\title{
Environmental Assessment of Tetracycline's Residues Detected in Pig Slurry and Poultry Manure
}

\author{
Matilde Carballo $^{1 *}$, Sonia Aguayo², Miguel González¹, Fernando Esperon ${ }^{1}$, Ana de la Torre1 \\ ${ }^{1}$ Research Centre in Animal Health, CISA-INIA, Madrid, Spain \\ ${ }^{2}$ Group of Water Pollution, ISC III, Madrid, Spain \\ Email: carballo@inia.es
}

Received 17 November 2015; accepted 9 January 2016; published 12 January 2016

Copyright @ 2016 by author and Scientific Research Publishing Inc.

This work is licensed under the Creative Commons Attribution International License (CC BY). http://creativecommons.org/licenses/by/4.0/

(c) (i) Open Access

\begin{abstract}
The widespread use of antimicrobials in animal husbandry has led to an increase in concentrations of antibiotics in animal faeces. Furthermore, the spreading of this waste as fertilizer on agricultural land indirectly introduces antimicrobial residues into the environment. This study examined samples of pig slurry and poultry manure for three tetracyclines-oxytetracycline (OTC), chlortetracycline (CTC) and doxycycline (DOC) and conducted an environmental evaluation of soils. The samples were taken from manure heaps on eight broiler chicken farms and from slurry ponds on eight pig farms. The tetracycline analysis was conducted using high-performance liquid chromatography combined with tandem mass spectrometry (HPLC/MS). The risk assessment was carried out on the basis of the estimated PECsoil value and the ecotoxicological information available for terrestrial organisms. TC concentrations were between $>0.01$ and $1.38 \mathrm{mg} / \mathrm{kg}$. OCT was detected in $37 \%$ of the poultry manure and in $20 \%$ of the pig slurry samples. DOC was present in $50 \%$ of pig slurry samples with an average concentration of $1.2 \mathrm{mg} / \mathrm{kg}$, while CTC was only found in one slurry sample at a concentration of $0.56 \mathrm{mg} / \mathrm{kg}$. Compared with published values for these two farm animals from other countries, the TC concentrations obtained in this study were low. The environmental importance of the data generated was also discussed.
\end{abstract}

\section{Keywords}

Tetracyclines, Pig Slurry, Poultry Manure, Risk Evaluation

\section{Introduction}

Over the past fifty years, a number of different antibiotics have been widely used in livestock farming. Tetracyc-

\footnotetext{
"Corresponding author.
}

How to cite this paper: Carballo, M., Aguayo, S., González, M., Esperon, F. and de la Torre, A. (2016) Environmental Assessment of Tetracycline's Residues Detected in Pig Slurry and Poultry Manure. Journal of Environmental Protection, 7, 82-92. http://dx.doi.org/10.4236/jep.2016.71008 
lines (TCs), broad-spectrum antibiotics active against a wide range of Gram $(+)$ and Gram $(-)$ bacteria, are among the oldest groups of veterinary chemotherapeutic substances in use and are the most successful class of antibiotics employed in veterinary health. The estimated consumption of TCs in food-producing animal species in Europe in 2012 was 3138 tons [1]. Although some of the administered TCs are metabolized or adsorbed in the animal's body, others are released in excreta as an unaltered form of the drug. Moreover, given that TCs are poorly absorbed by animal tissues, the excreted part is usually significant [2]. It has been reported that over 70\% of administered chlortetracycline (CTC) and doxycycline (DOC), and over 80\% of oxytetracycline (OTC), are excreted in their original forms [3]. Indeed, concentrations of up to $20 \mathrm{mg} / \mathrm{L}$ of tetracycline have been reported from animal manure [4]. Much of the animal manure treated with antibiotics is spread on agricultural land and TCs are subsequently released into the soil. The characteristics of TCs—above all, their persistence and adsorption coefficients-favour their accumulation in soil and TC residues are detected in fertilized soils [5]-[7]. The presence of TCs in soil ecosystems can have adverse effects on terrestrial organisms and lead to the selection of antibiotic-resistant bacteria [7] [8]. Despite these concerns, reports of the occurrence of these antimicrobials in animal manure and soils are still very scarce.

Spain had a very well developed animal-husbandry sector and data from 2013, it had showed that it was the world's fourth most important porcine producer (second in the EU after Germany) and third most important poultry (broiler chicken) producer (after France and the UK). It is calculated that annually these food-producing animals produce 120 million tons of animal waste, which represent around $8.5 \%$ of the EU's total manure output [9]. Most of the manure produced by the animal industry is currently applied to agricultural land as a source of nutrients and soil amendment. The consumption of TCs in Spain as veterinary medicines was high and, for example, it was estimated at around 350 tonnes in 2012 [1]. It is thus vital to study the antimicrobial content of these animal manures. Data for cattle are previously published [10], and there is still a lack of relevant information for pigs and poultry. The aim of this study is to investigate the occurrence of three tetracyclines-oxytetracycline (OTC), chlortetracycline (CTC) and doxycycline (DOC) — in pig slurry and poultry manure. Given that these sub-products are used as fertilizers, we also evaluated the environmental risk to terrestrial organisms provoked by the application of manure to agricultural land.

\section{Materials and Methods}

\subsection{Collection of Manure Samples}

Sixteen manure samples were collected from eight pig and eight poultry farms in the Autonomous Community of Castilla-Leon (Spain). The sizes of the farms ranged from 15,000 - 20,000 animals for broiler chicken farms and 2000 - 3500 animals for pig farms. Sampling was carried out in April 2011-May 2012. Each manure sample was prepared by mixing an equal amount of 5 - 10 discrete sub-samples to obtain a single sample of approximately $2000 \mathrm{~g}$ (or 3 litres) of manure mixture from each farm. Poultry manure consists of the mixture of urine, faeces and litter generated on poultry farms, which is stored in large heaps outside broiler chicken sheds. Pig slurry samples were taken directly from tanker lorries before being applied to fields. These tankers are loaded with pig slurry from storage ponds that have previously been mechanically stirred. Pig slurry is a mixture of urine, faeces and the water used to wash out the pigs, and is stored in pools for at least three months before being spread on fields. All samples were stored in plastic containers and immediately taken to the laboratory, where they were refrigerated at $-20^{\circ} \mathrm{C}$. The manure samples were physico-chemically characterized following Standard Method procedures; the parameters determined were total, Kjeldahl nitrogen, organic matter and dried weight.

\subsection{Chemical Analysis of the TCs}

The chemical analysis of the TCs, described below, was conducted following Carballo et al., 2013 [10] (Figure 1) with slight modifications, mainly in the way in which samples were treated.

\subsubsection{Sample Extraction and Clean-Up}

Before analysis, poultry samples were dried for $24 \mathrm{hrs}$ at $60^{\circ} \mathrm{C}$ and then ground and passed through a 2-mm sieve. Pig slurry samples were first shaken and then placed in $400-\mathrm{mL}$ containers, where they were left at $60^{\circ} \mathrm{C}$ until completely dry (about 24 hours). Sediments from the bottom of the containers were scraped out and combined into a single sample that was ground and sieved. A total of $0.5 \mathrm{~g}$ of dust obtained from the samples were added to $30 \mathrm{ml}$ 


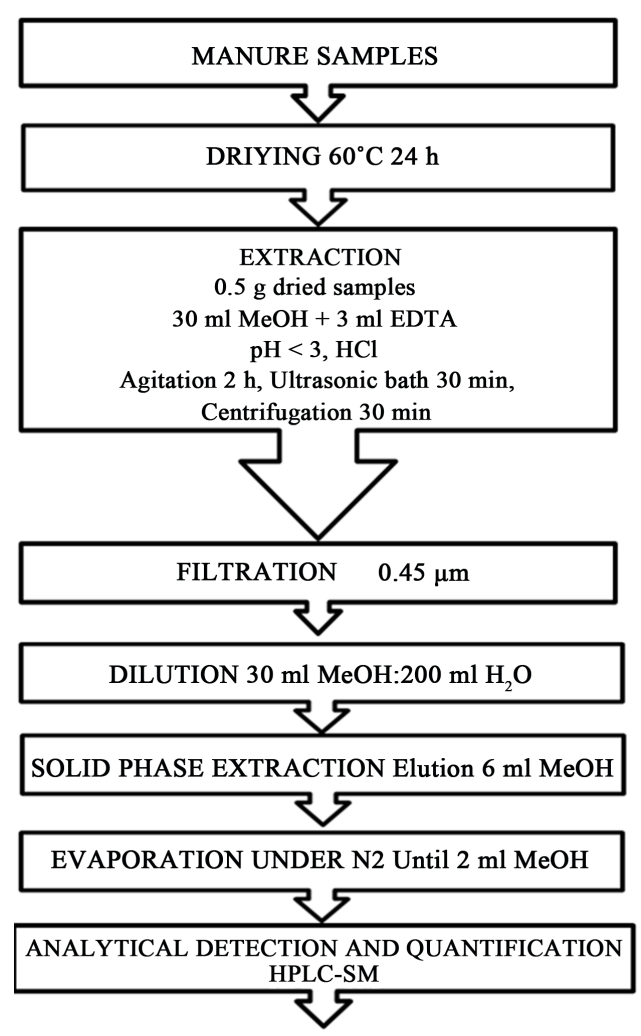

Figure 1. Chemical analysis of tetracyclines.

methanol and $3 \mathrm{ml}$ EDTA $\left(3 \times 10^{-3} \mathrm{M}\right)$. The tetracyclines were extracted under acidic conditions. The $\mathrm{pH}$ of the solution was adjusted to below 3 using hydrochloric acid $(2.5 \mathrm{M})$. The mixture was agitated automatically at 300 $\mathrm{rpm}$ for $2 \mathrm{hrs}$ and then placed in an ultrasonic bath $\left(18^{\circ} \mathrm{C}\right)$ for $30 \mathrm{~min}$ and centrifuged at $4^{\circ} \mathrm{C}$ approximately at $2500 \mathrm{rpm}$ for 30 mins. The resultant supernatant was decanted into a glass bottle, filtered through a $0.45-\mu \mathrm{m}$ membrane filter (PVDF Acrodis ${ }^{\circledR}$ LC, Pall, USA) and diluted with water (30 ml methanol:200 ml water). The methanol/water solution was passed through a Water Oasis HLB cartridge (Waters, Milford MA, USA), previously prepared with $20 \mathrm{ml}$ methanol: $10 \mathrm{ml}$ Milli-Q water, at a flow rate of $10 \mathrm{~mL} / \mathrm{min}$ to concentrate and purify the diluted manure extract. In the final step, the cartridges were washed (water and methanol 5\%), dried under nitrogen flows, eluted from the cartridge with $6 \mathrm{ml}$ methanol, and finally concentrated to $2 \mathrm{ml}$ under nitrogen flows. This residue in the methanol was used for the HPLC/MS analysis.

\subsubsection{Analytical Quantification}

The concentrations of the three selected antibiotics-Oxytetracycline (OTC) (Aldrich 05875-10 g), Doxycyline (DOC) (Sigma D9892) and Clortetracycline (CTC) (Fluka 46133); all of >99\% purity—were determined using high-performance liquid chromatography combined with tandem mass spectrometry (HPLC/MS). Stock solutions of the standards were prepared monthly by dissolving each compound in methanol at concentration $1 \mathrm{mg} / \mathrm{mL}$ and storing at $-20^{\circ} \mathrm{C}$. The equipment used consisted of a HPLC Water 2690 Alliance with automatic autosampler. A Gemini-NX-C18 column $(4.6 \times 150 \mathrm{~mm}, 5-\mu \mathrm{m}$ pore size, Phenomenex $)$ thermostated at $25^{\circ} \mathrm{C}-30^{\circ} \mathrm{C}$ was used to separate the antibiotics. Gradient elution was carried out with acetonitrile and methanol with $5 \mathrm{mM}$ of oxalic acid (1:1) (mobile phase A) and oxalic acid (5 mM) in 99.9\% Milli-Q water (v/v) (mobile-phased B). The injection volume was $5 \mu \mathrm{l}$ and the flow rate was $0.2 \mathrm{~mL} / \mathrm{min}$. The separation of the antibiotics was conducted using a gradient program as follows: A:B was 10:90 and maintained at $0 \mathrm{~min}$ for $18 \mathrm{~min}, 40: 60$ for $2 \mathrm{~min}, 90: 10$ for $6 \mathrm{~min}$, and maintained 8 mins at 10:90 for column equilibration. All three antibiotics were eluted within $28 \mathrm{~min}$. A Waters 3100 Mass Detector using a positive electrospray ionisation (ESI+) source and operated in the positive ion mode was used. The ESI source values were as follows: capillary voltage $4.5 \mathrm{kV}$, cone voltage $30 \mathrm{~V}$, source temperature $120^{\circ} \mathrm{C}$, desolvation temperature $400^{\circ} \mathrm{C}$, and desolvation and cone gas pressures 24 and 50 psi, respectively. The 
precursor parent ion $[\mathrm{M}+\mathrm{H}]^{+}$(oxitetracycline: $461.2 \mathrm{~m} / \mathrm{z}$, doxycycline: $445.1 \mathrm{~m} / \mathrm{z}$, chlortetracycline: $479.0 \mathrm{~m} / \mathrm{z}$ ) was used for quantification in the selected ion recording (SIR) mode for each antibiotic, while the daughter ion product (oxytetracycline: $426.2 \mathrm{~m} / \mathrm{z}$, doxycycline: $428.2 \mathrm{~m} / \mathrm{z}$, chlortetracycline: $444.0 \mathrm{~m} / \mathrm{z}$ ) was used for confirmation purposes. The chromatogram of OTC in pig slurry is show in Figure 2.

\subsubsection{Method Validation}

Analytical procedures were checked for linearity, accuracy and precision, limit of detection (LOD) and limit of quantification (LOQ). Concentrations in the samples were calculated by external standard methods based on the peak area of the monitored daughter product. The repeatability of the HPLC/MS method was evaluated by the injection of standard solutions $(1,3,5 \mu \mathrm{g} / \mathrm{l})$ into the system. The standard solutions were prepared from the corresponding stock solutions $(2 \mathrm{mg} / \mathrm{ml} \mathrm{MeOH})$ by subsequent dilutions. Results indicate that good linearity was achieved $\left(r^{2}>0.8\right)$ for the calibration curves of all selected antibiotics in the studied concentration range. The analyses of the three TCs were checked for linearity $r^{2}=0.97-0.99$. The linearity of the response was determined by preparing solutions containing $0.5,1.0,3.0 \mathrm{mg} / \mathrm{l}$ of OTC, DOC and CTC, respectively, and each were injected into duplicates on the HPLC system. The intercept and correlation coefficient R were calculated from the results slope. By applying the proposed method, linearity was obeyed in the concentration range $0.5-3 \mathrm{mg} / \mathrm{l}$ and the correlation coefficient of 0.99 for the compound indicated good linearity between the concentration and peak area. The slope value $3 \times 10^{6}$ is good evidence of the sensitivity of the HPLC method. Recoveries for the entire procedure were determined using samples taken from the farms. To determine the influence of different matrices on the HPLC/MS analyses, manure samples were fortified with OTC, DOC and CTC at three concentration levels (approximately $3 \mathrm{mg} / \mathrm{kg}$ ). Since these fortified samples contained the target compounds, blank samples were extracted and analysed using the complete procedure. For each matrix and concentration, recoveries were determined using triplicate samples to compare the obtained concentrations with the initial fortified levels.

\subsection{Statistical Analysis}

The variations in the average of each tetracycline concentration among the different types of manure were conducted by T-Student, significant level were at $p>0.05$. Statistical analyses were conducted using SPSS v.15.0 software.

\subsection{Risk Assessment}

The risk assessment for the soil was calculated as a hazard quotient (HQ), as recommended by the EMEA [11]. $\mathrm{HQ}$ is the quotient of the predicted environmental concentration (PEC) and the predicted no-effect concentration (PNEC). The predicted environmental concentration in soil $\left(\mathrm{PEC}_{\text {soil }}\right)$ was estimated using the antibiotic concentrations in the manure samples and the nitrogen richness of the manure (Table 1) following the indications in the

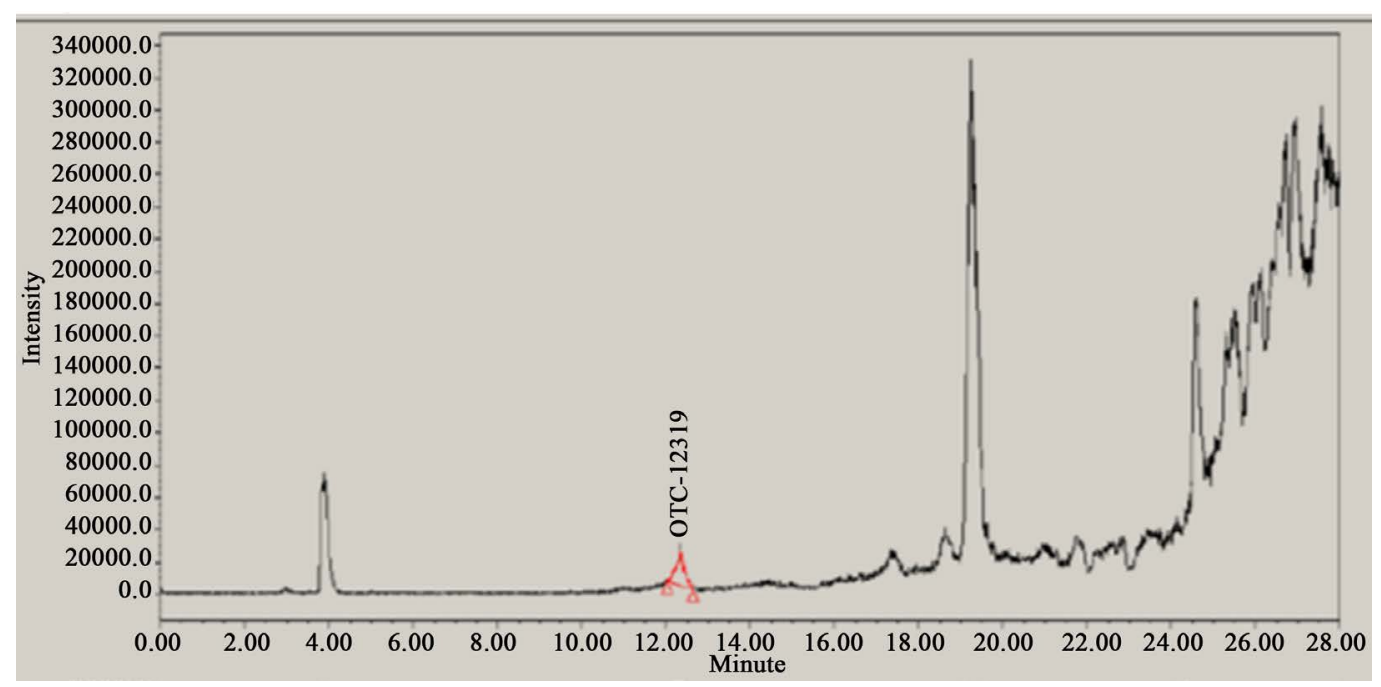

Figure 2. A chromatogram of OTC in pig slurry. 
Table 1. Composition of the manure samples analyses.

\begin{tabular}{cccccccc}
\hline $\begin{array}{c}\text { Poultry } \\
\text { Manure }\end{array}$ & $\begin{array}{c}\text { Dried } \\
\text { Weight }(\%)\end{array}$ & $\begin{array}{c}\text { Organic } \\
\text { Matter }(\%)\end{array}$ & $\begin{array}{c}\text { N-Kjeldalh } \\
(\mu \mathrm{g} / \mathrm{g})\end{array}$ & Pig Slurry & $\begin{array}{c}\text { Dried } \\
\text { Weight }(\%)\end{array}$ & $\begin{array}{c}\text { Organic } \\
\text { Matter }(\%)\end{array}$ & $\begin{array}{c}\text { N-Kjeldalh } \\
(\mu \mathrm{g} / \mathrm{g})\end{array}$ \\
\hline A1 & 78.4 & 73.0 & 38.700 & $\mathrm{P} 1$ & 8.31 & 7.89 & 72.400 \\
A2 & 82.0 & 76.3 & 34.600 & $\mathrm{P} 2$ & 1.23 & 0.86 & 61.300 \\
A3 & 75.9 & 70.1 & 37.600 & P3 & 2.46 & 1.69 & 50.000 \\
A4 & 72.6 & 67.5 & 35.300 & P4 & 7.97 & 6.29 & 28.900 \\
A5 & 69.2 & 64.4 & 39.078 & P5 & 2.30 & 1.63 & 62.700 \\
A6 & 76.4 & 72.6 & 32.900 & P6 & 2.98 & 2.06 & 64.000 \\
A7 & 45.9 & 40.2 & 40.300 & P7 & 7.83 & 4.68 & 35.200 \\
A8 & 56.5 & 53.1 & 44.804 & P8 & 4.98 & 3.46 & 43.400 \\
\hline
\end{tabular}

EMEA's guidelines regarding the amount of manure that can be applied to the soil as fertilizer (nitrogen spreading limit: $170 \mathrm{NT} / \mathrm{Ha}, 1500 \mathrm{~kg} / \mathrm{m}^{3}$ soil density and soil depth of $0.05 \mathrm{~m}$ ). The PNEC was calculated using ecotoxicological information on terrestrial organisms (microorganisms, plants and earthworms) taken from the published literature. A short-term ( $\mathrm{CL}_{50}$ ) or long-term (NOEC) value and a safety factor were applied depending on the toxicity data. The lower toxic value was selected and compared with the $\mathrm{PEC}_{\text {soil }}$ value. If the ratio PEC/PNEC was higher than 1, environmental risk was judged to be present. In addition, the minimum inhibitory concentration (MIC) values for microorganisms from the EUCAST database [12] and scientific journals were searched for and compared with the $\mathrm{PEC}_{\text {soil }}$.

\section{Results and Discussion}

\subsection{TCs Residues in Animal Manure}

Table 2 shows the recovery percentages for each TC and for each type of manure analysed, as well as the limits of detection (LOD) and quantification (LOQ). Table 3 contains the frequency of appearance of each compound in terms of the type of manure, and the detected concentrations of all three TCs; also given are the maximum and mean values of the concentrations (the lowest values were always below the limit of quantification). The concentration of TCs are no significantly $(p<0.05)$ different in the two types of manure. TCs were detected in the range $<0.01-1.38 \mathrm{mg} / \mathrm{kg}$. OTC was found in $25 \%$ of the pig slurry samples, with a maximum value of $0.72 \mathrm{mg} / \mathrm{kg}$; DOC was present in 50\% of the samples, with average values of $0.63 \mathrm{mg} / \mathrm{kg}$; finally, CTC was only found in one of the pig slurry samples $(0.56 \mathrm{mg} / \mathrm{kg})$. Only two TCs were detected in the poultry manure: OTC in 37\% of samples, with a maximum concentration of $0.88 \mathrm{mg} / \mathrm{kg}$, and DOC in just one sample. With the exception of CTC in poultry manure, the highest concentration values were all over $100 \mu \mathrm{g} / \mathrm{kg}$. Table 4 gives the values for the TC levels found in pig slurry and poultry manure [13]-[25] from a number of other countries; in general, studies of TCs in animal waste are scarce. CTC is the commonest tetracycline found in pig slurry and is present at the highest concentrations $(0.046$ - $404 \mathrm{mg} / \mathrm{kg})$, followed by OTC $(0.007$ - $173 \mathrm{mg} / \mathrm{kg})$. In poultry manure, the compound found at greatest concentrations is OTC $(0.06-183 \mathrm{mg} / \mathrm{kg})$, followed by CTC $(0.06173 \mathrm{mg} / \mathrm{kg})$ and DOC (0.3 $78.5 \mathrm{mg} / \mathrm{kg}$ ). The highest recorded concentrations are from the USA, Korea and China, countries that all consume large amounts of tetracyclines not only in the treatment and prevention of animal diseases but also as food supplements to promote growth. The concentrations found in this study $-<0.01-1.38 \mathrm{mg} / \mathrm{kg}$ —are low in comparison. It is important to note that the studied samples were collected just before they were applied to fields. The liquid pig waste is stored in ponds for at least three months, during which time tetracyclines may undergo certain modifications. In the slurry ponds important changes in temperature and in oxygen levels occur, which could create conditions that affect tetracyclines. Thus, [26] detected that CTC concentrations decrease in pig slurry when exposed to high temperatures $\left(22^{\circ} \mathrm{C}-50^{\circ} \mathrm{C}\right)$ and that the degradation of CTC is dependent on temperature, with higher temperatures increasing degradation. Anaerobic conditions also affect CTCs [26] and under these circumstances most CTCs degrade to iso-chlortetracycline [21], a chemical form that is biologically inactive. Solid animal waste such as poultry manure is stored in large heaps in which a series of transformations such as com- 
Table 2. Analytical characteristics.

\begin{tabular}{rcccccc}
\hline & \multicolumn{3}{c}{ Poultry Manure } & \multicolumn{3}{c}{ Pig Slurry } \\
\cline { 2 - 7 } & Recovery (\%) & LOD (mg/kg) & LOQ (mg/kg) & Recovery (\%) & LOD (mg/kg) & LOQ (mg/kg) \\
\hline OTC & 80 & 0.09 & 0.14 & 83 & 0.3 & 0.40 \\
DOC & 73 & 0.01 & 0.34 & 75 & 0.1 & 0.32 \\
CTC & 75 & 0.03 & 0.18 & 80 & 0.07 & 0.21 \\
\hline
\end{tabular}

LOD: Limit of detection; LOQ: Limit of quantification. OTC: Oxytetracycline, DOC: Doxycyline, CTC: Clortetracycline.

Table 3. Frequency and detected concentration (mean levels* and maximum values) of three tetracycline’s in manures.

\begin{tabular}{lcccccc}
\hline & \multicolumn{3}{c}{ Poultry Manure } & \multicolumn{3}{c}{ Pig Slurry } \\
\cline { 2 - 7 } & Frequency (\%) & Mean (SD) (mg/kg) & Maximum (mg/kg) & Frequency (\%) & Mean (SD) (mg/kg) & Maximum (mg/kg) \\
\hline OTC & 37 & $0.27(0.38)$ & 0.88 & 62 & $0.28(0.29)$ & 0.72 \\
DOC & 12 & $0.06(0.18)$ & 0.53 & 75 & $0.63(0.63)$ & 1.38 \\
CTC & 0 & - & - & 37 & $0.08(0.19)$ & 0.56 \\
\hline
\end{tabular}

OTC: Oxytetracycline, DOC: Doxycyline, CTC: Clortetracycline, SD: standard deviation. ( $\left(^{*}\right)$ To calculate mean, value of LOD (limit of detection) was taken when values are $<$ LOQ (limit of quantification) and values below LOD were considered.

Table 4. Tetracycline antibiotics concentrations in pig slurries and poultry manure. Mean value (minimum-maximum) (mg/kg).

\begin{tabular}{|c|c|c|c|c|}
\hline & Pig Slurry & References & Poultry Manure & References \\
\hline OCT & $\begin{array}{c}11.8(0.73-57) \\
0.03(0.007-0.06) \\
63(0.21-126) \\
0.05(0.03-0.078) \\
26.8 \\
14.6(0.21-29) \\
91.3(9.7-173) \\
1.11(0.02-43.4)\end{array}$ & $\begin{array}{l}{[13]} \\
{[14]} \\
{[15]} \\
{[16]} \\
{[17]} \\
{[18]} \\
{[19]} \\
{[20]}\end{array}$ & $\begin{array}{c}0.062 \\
183 \\
1.55 \\
6.45(0.96-13) \\
0.71(0.02-416)\end{array}$ & $\begin{array}{l}{[23]} \\
{[17]} \\
{[24]} \\
{[13]} \\
{[20]}\end{array}$ \\
\hline CTC & $\begin{array}{c}1-7 \\
404 \\
1.0(0.02-215) \\
(0.8-1.5) \\
(0.1-46) \\
5.9 \\
(0.6-42)\end{array}$ & $\begin{array}{l}{[14]} \\
{[21]} \\
{[20]} \\
{[16]} \\
{[18]} \\
{[22]} \\
{[19]}\end{array}$ & $\begin{array}{c}1.29(0.57-3.1) \\
0.07(0.057-0.1) \\
0.3-173 \\
1.7 \\
1.1 \\
0.02(0.014-0.13)\end{array}$ & $\begin{array}{l}{[13]} \\
{[23]} \\
{[19]} \\
{[18]} \\
{[24]} \\
{[20]}\end{array}$ \\
\hline DOC & $0.64(0.01-30)$ & [20] & $\begin{array}{c}3.39 \\
22(0.3-78.5) \\
0.1(0.02-8.3)\end{array}$ & $\begin{array}{l}{[24]} \\
{[25]} \\
{[20]}\end{array}$ \\
\hline
\end{tabular}

OTC: Oxytetracycline, DOC: Doxycyline, CTC: Clortetracycline.

posting take place. This controlled aerobic process implies the presence of different groups of micro-organisms that aid the decomposition of organic matter and gives rise to more stable organic and inorganic products. During this process and as a result of the intense biological activity, temperatures may rise above $40^{\circ} \mathrm{C}$ and humidity may reach $40 \%$ - 60\%. It has been reported that composting can degrade the CTC present in animal manure [27], although its disappearance is slow given that the particles of matter will offer it a certain degree of protection. Thus, the storing of animal waste may stimulate processes that are effective in reducing concentrations of TCs in animal waste. 


\subsection{Potential Risk Assessment of TCs in Animal Manure}

A risk evaluation of the three TCs detected in this study was conducted. The predicted environmental concentration in the soil $\left(\mathrm{PEC}_{\text {soil }}\right)$ was estimated following the recommendations contained in the guidelines for the risk evaluation of veterinary medicines [1] [28]. The calculations were carried out using the highest TC concentrations detected in this study and the nitrogen content of the samples (Table 1). The estimation of the $\mathrm{PEC}_{\text {soil }}$ in soil spread with poultry manure gave values of $5.2 \mu \mathrm{g} / \mathrm{kg}$ for OTC and $3.2 \mu \mathrm{g} / \mathrm{kg}$ for DOC, while in soils treated with pig slurry OTC concentrations were estimated at $3 \mu \mathrm{g} / \mathrm{kg}$, CTC concentrations at $2 \mu \mathrm{g} / \mathrm{kg}$ and DOC concentrations at $6 \mu \mathrm{g} / \mathrm{kg}$. The estimated $\mathrm{PEC}_{\text {soil }}$ in all cases was below $100 \mathrm{ug} / \mathrm{kg}$, the threshold value of Directive 81/852/EEC [28] for environmental impact assessment. Thus, no risk to soil organisms is expected to exist.

A number of different studies haveshown that TCs are the most frequently detected antibiotics in agricultural soils fertilized with animal manure. CTC has been detected at 4.6 - $93 \mu \mathrm{g} / \mathrm{kg}$ [7] [16] [17] [29] and OTC at 3.9 $305 \mu \mathrm{g} / \mathrm{kg}$ [5] [15]. In the countries with the largest livestock populations and the greatest consumption of TCs, the quantity of TCs found in soils is significantly higher [30]. In general, the environmental concentrations of TCs in soils in European countries are largely below $100 \mu \mathrm{g} / \mathrm{kg}$, although a few "hotspots" may exist where concentrations are higher. Although the extensive use of these compounds and the recurrent spreading of animal manure on fields favour their appearance in soils, another factor to take into account is the nature of these molecules (Table 5). Tetracycline antibiotics are highly hydrophilic character, with low volatility and a great adsorption capacity, characteristics that allow them to bond with the organic matter in the soil and form highly stable complexes [17] [30]-[33]. The degradation of TCs is thus slow ( $\mathrm{DT}_{50}=18-76$ days). This moderate-high persistence, together with the continuous introduction of TCs into soils, ensures that residual concentrations are maintained in the soil (pseudo-persistence), which explains why these compounds are frequently detected in certain soils. Studies of the degradation of TCs in the field indicate that the combined effects of the action of soil micro-organisms and environmental conditions may help accelerate this degradation [6] although more studies are still necessary to broad our knowledge of this question.

The Environmental Risk Assessment Guide [11] requires a mandatory evaluation of the effects of TCs when a threshold is reached, and recommends methodologies for determining whether TCs (and antimicrobials in general) pose a threat to soil organisms. This has encouraged the obtaining of ecotoxicity data for, above all, the species recommended in this guideline that belong to three different taxonomic groups: micro-organisms, plants and invertebrates (e.g. earthworms). The endpoints that are most often evaluated are changes in weight, survival and breeding parameters. Ecotoxic data show that DOC may inhibit the microbial nitrogen transformation to nitrate in soils when concentrations rise above $0.2 \mathrm{mg} / \mathrm{kg}$ [34] [35] and that acute toxicity in plants $\left(\mathrm{EC}_{50}\right)$ is reached at 66 $150 \mathrm{mg} / \mathrm{kg}$. CTC can inhibit the nitrification of the soils at concentrations $>100 \mathrm{mg} / \mathrm{kg}$ [36]. Among plants, maize seems to be one of the most sensitive species to CTC and root elongation, the most sensitive endpoint, has an $\mathrm{EC}_{50}$ $=2.28 \mathrm{mg} / \mathrm{kg}$ for this parameter [37] [38]. The effects of TCs on wheat only appear at higher concentrations [39].

Table 5. Selected properties of tetracyclines.

\begin{tabular}{|c|c|c|c|}
\hline & CTC & OTC & DOC \\
\hline Molecular weight (g/mol) & 515.3 & 496.9 & 444.4 \\
\hline Water solubility (mg/L) & 500 & 300 & 630 \\
\hline Vapour Pressure (mPa) & $2.09 \times 10^{-23}$ & $1.29 \times 10^{-19}$ & $1.89 \times 10^{-18}$ \\
\hline $\begin{array}{l}\text { Dissociation constants in water } \\
\qquad \mathrm{Pka}^{1} \\
\mathrm{Pka}^{2} \\
\mathrm{Pka}^{3}\end{array}$ & $\begin{array}{l}3.3 \\
7.5 \\
9.3\end{array}$ & $\begin{array}{l}3.2 \\
7.4 \\
8.9\end{array}$ & $\begin{array}{l}3.4 \\
7.7 \\
9.3\end{array}$ \\
\hline Octanol-water partition coefficient (log $\mathrm{K}_{\mathrm{ow}}$ ) & -0.62 & -1.22 & -0.02 \\
\hline Organic carbon partition coefficient ( $\mathrm{K}_{\mathrm{oc}} \mathrm{l} / \mathrm{kg}$,) & 76,423 & $\begin{array}{c}52,875 \\
(27,792-93,317)\end{array}$ & $\begin{array}{c}36,448 \\
(15,161-11,4815)^{* * *}\end{array}$ \\
\hline Desorption potential $\left(\mathrm{K}_{\mathrm{d}}, \mathrm{l} / \mathrm{kg}\right)$ & $\begin{array}{c}501-3715 \\
(1280-2386)^{*}\end{array}$ & $\begin{array}{c}950-7200 \\
(420-1030)^{* *}\end{array}$ & $\begin{array}{c}779 \\
(338-1819)\end{array}$ \\
\hline Half-lifein soil ( $\mathrm{DT}_{50 \text { soil, days) }}$ & $18-42$ & $18-56$ & $59-76$ \\
\hline
\end{tabular}

OTC: Oxytetracycline, DOC: Doxycyline, CTC: Clortetracycline. [31], ${ }^{*}[32],{ }^{* *}[17],{ }^{* * *}[33]$. 
OTC affects the enzymatic activity of soil micro-organisms at concentrations of $>15 \mathrm{mg} / \mathrm{kg}$ and at $200 \mathrm{mg} / \mathrm{kg}$ its effect on the growth of soil micro-organisms becomes patent [40]. The effects of this antibiotic on wheat were investigated by An et al. [41]. These authors found that OTC can inhibit shoot and root elongation, and report $\mathrm{EC}_{50}$ $=65.5 \mathrm{mg} / \mathrm{L}$ and $34.7 \mathrm{mg} / \mathrm{L}$ (respectively) for these parameters. Studies of the effects of CTC, OTC and DOC on the earthworm (Eisenia fetida) indicate that this invertebrate is highly insensitive to the acute effects of TCs. Mortality rates in adult earthworms have been reported as $\mathrm{LC}_{50}>1000 \mathrm{mg} / \mathrm{kg}$ [42] [43], although effective concentrations in juveniles and cocoon counts are lower ( 96.1 and $120.3 \mathrm{mg} / \mathrm{kg}$, respectively). Low concentrations of CTC (30 mg/kg) can induce physiological changes and genotoxic effects in earthworms [44]. Nevertheless, data for the toxicity of TCs in terrestrial organism are still scarce and various authors have highlighted the need to improve our knowledge of this issue as a means of evaluating more precisely the effects of TCs given that these organisms may be subject to prolonged exposure.

Another relevant environmental concern is the presence of antibiotic-resistant bacteria, selected due to repeated exposure to sub-lethal doses of antibiotics [5], in agricultural fields fertilized with animal manure containing residues of TCs (and other antimicrobials). It has been suggested that the selection of resistant bacteria could occur at antibiotic concentrations that are greater than the minimal inhibitory concentration (MIC) of susceptible bacteria. MIC values for DOC in different bacteria are in the range $1-2 \mathrm{mg} / \mathrm{L}$ (ppm) (EUCAST database) and for CTC is over 4 ppm [45]. However, the estimated concentrations for the studied soils differ greatly from these levels. Nevertheless, recent studies indicate that concentrations lower than the MIC, that is, sub-MIC levels, could enrich selectively the resistant bacteria present in the environment. Thus, several authors [46] [47] suggest that the minimal selective concentration (MSC) could in fact be up to 100 times lower than the MIC and still favour this enrichment process. This would mean that the concentrations of antibiotics found in agricultural soils could be high enough to enrich these environments with resistant bacteria [47]. Existing information needs to be improved in order to fully appreciate the relationship between the presence of residual concentrations of antibiotics such as tetracyclines and antibiotic-resistant micro-organisms.

\section{Conclusion}

In this study of antimicrobials in animal manure in Spain, tetracycline residues were detected in $56 \%$ of the manure samples, TCs were detected in the range $<0.01-1.38 \mathrm{mg} / \mathrm{kg}$. The estimated concentrations of OTC, CTC and DOC in soils $\left(\mathrm{PEC}_{\text {soil }}\right.$ ) were relatively low and were under $100 \mu \mathrm{g} / \mathrm{kg}$. Nevertheless, the inherent characteristics of these compounds and the cyclical application of manure containing residual concentrations of antimicrobials on agricultural fields ensured that terrestrial organisms suffered prolonged exposure to these compounds. Thus, we believed that studies of agricultural soils must be broadened to determine the true extent of the risk posed by this use of animal waste products. Likewise, we felt that it was important to encourage the use of properly treated agricultural residues if antibiotic concentrations in agricultural soils were to be reduced.

\section{Acknowledgements}

This work was funded by the Spanish Ministry of the Environment and Marine Affairs and the National Institute for Agriculture and Food Research and Technology RTA2010-00066-C02-01. We would like to thank the Agrarian Reuse of Livestock Residue group of the Environment Department of INIA for their help in the analysis of the manures.

\section{References}

[1] European Medicines Agency (EMA) (2014) Sales of Veterinary Antimicrobial Agents in 26 EU/EEA Countries in 2012. EMA/333921/2014.

[2] Arikan, O.A., Mulbry, W. and Rice, C. (2009) Management of Antibiotic Residues from Agricultural Sources: Use of Composting to Reduce Chlortetracycline Residues in Beef Manure from Treated Animals. Journal Hazardous Materials, 164, 483-489. http://dx.doi.org/10.1016/j.jhazmat.2008.08.019

[3] Hirsch, R., Ternes, T., Haberer, K. and Kratz, K.L. (1999) Occurrence of Antibiotics in the Aquatic Environment. Science of the Total Environment, 225, 109-118. http://dx.doi.org/10.1016/S0048-9697(98)00337-4

[4] Winckler, C. and Grafe, A. (2001) Use of Veterinary Drugs in Intensive Animal Production. Journal of Soils and Sediments, 1, 66-70. http://dx.doi.org/10.1007/BF02987711

[5] Kemper, N. (2008) Veterinary Antibiotics in the Aquatic and Terrestrial Environment. Ecological Indicators, 8, 1-13. 
http://dx.doi.org/10.1016/j.ecolind.2007.06.002

[6] Du, L. and Liu, W. (2012) Occurrence, Fate and Ecotoxicity of Antibiotics in Agro-Ecosystems: A Review. Agronomy for Sustainable Development, 32, 309-327. http://dx.doi.org/10.1007/s13593-011-0062-9

[7] Daghrir, R. and Drogui, P. (2013) Tetracycline Antibiotics in the Environment. A Review. Environmental Chemistry Letters, 11, 209-227. http://dx.doi.org/10.1007/s10311-013-0404-8

[8] Kumar, K., Gupta, S.C., Chander, Y. and Singh, A.K. (2005) Antibiotic Use in Agriculture and Its Impacts on the Terrestrial Environment. Advances in Agronomy, 87,1-54. http://dx.doi.org/10.1016/S0065-2113(05)87001-4

[9] Ministerio Agricultura, Pesca y Alimentación (MAPA) (2007) Libro Blanco de Subproductos de Origen Animal No Destinados a Consumo Humano (SANDACH). Capitulo VI.-Valorización de los SANCHA, Madrid, 155.

[10] Carballo, M., Esperón, E., Sacristán, C., González, M., Vázquez, B., Aguayo, S. and De la Torre, A. (2013) Occurrence of Tetracycline Residues and Antimicrobial Resistance in Gram Negative Bacteria Isolatesfrom Cattle Farms in Spain. Advances in Bioscience and Biotechnology, 4, 295-303. http://dx.doi.org/10.4236/abb.2013.42A040

[11] European Medicines Agency (EMEA) (2008) Guideline on Environmental Impact Assessment for Veterinary Medicinal Products. In Support of the VICH Guideline GL6 and GL38. EMEA/CVMP/ERA/418282/2005-Rev.1.

[12] EUCAST (2015) European Committee on Antimicrobial Susceptibility Testing. http://mic.eucast.org/Eucast2/SearchController/search.jsp?action=init

[13] Li, Y., Zhang, X., Li, W., Lu, X., Liu, B. and Wang, J. (2013) The Residues and Environmental Risks of Multiple Veterinary Antibiotics in Animal Faeces. Environmental Monitoring and Assessment, 185, 2211-2220. http://dx.doi.org/10.1007/s10661-012-2702-1

[14] Zhang, Y., Zhang, C., Parker, D.B., Snow, D.D., Zhou, Z. and Li, X. (2013) Occurrence of Antimicrobials and Antimicrobial Resistance Genes in Beef Cattle Storage Ponds and Swine Treatment Lagoons. Science of the Total Environment, 463-464, 631-638. http://dx.doi.org/10.1016/j.scitotenv.2013.06.016

[15] Boxall, A.B.A., Johnson, P. and Smith, E. (2006) Uptake of Veterinary Medicines from Soils into Plants. Journal of Agricultural Food and Chemistry, 54, 2288-2297. http://dx.doi.org/10.1021/jf053041t

[16] Hamscher, G., Sczesny, S., Hoper, H. and Nau, H. (2002) Determination of Persistent Tetracycline Residues in Soil Fertilized with Liquid Manure by High-Performance Liquid Chromatography with Electrospray Ionization Tandem Mass Spectrometry. Analytical Chemistry, 74, 1509-1518. http://dx.doi.org/10.1021/ac015588m

[17] Kim, K.R., Owens, G., Kwon, S.I., So, K.H., Lee, D.B. and Ok, Y.S. (2011) Occurrence and Environmental Fate of Veterinary Antibiotics in the Terrestrial Environment. Water, Air and Soil Pollution, 214, 163-174. http://dx.doi.org/10.1007/s11270-010-0412-2

[18] Martínez-Carballo, E., González-Barreiro, C., Scharf, S. and Gans, O. (2007) Environmental Monitoring Study of Selected Veterinary Antibiotics in Animal Manure and Soils in Austria. Environmental Pollution, 148, 570-579. http://dx.doi.org/10.1016/j.envpol.2006.11.035

[19] Hu, X.G., Zhou, Q.X. and Xu, L. (2008) Determination of Thirteen Antibiotics Residues in Manure by Solid Phase Extraction and High Performance Liquid Chromatography. Chinese Journal of Analytical Chemistry, 36, 1162-1166. http://dx.doi.org/10.1016/S1872-2040(08)60063-8

[20] Zhang, H., Luo, Y., Wu, L., Huang, Y. and Christie, P. (2015) Residues and Potential Ecological Risks of Veterinary Antibiotics in Manures and Compost Associated with Protected Vegetable Farming. Environmental Science Pollution Research, 22, 5908-5918. http://dx.doi.org/10.1007/s11356-014-3731-9

[21] Joy, S.R., Li, X., Snow, D.D., Gilley, J.E., Woodbury, B. and Bartelt-Hunt, S.L. (2013) Fate of Antimicrobials and Antimicrobial Resistance Genes in Simulated Swine Manure Storage. Science of the Total Environment, 481, 69-74. http://dx.doi.org/10.1016/j.scitotenv.2014.02.027

[22] Tylová, T., Olšovská, J., Novák, P. and Flieger, M. (2010) High-Throughput Analysis of Tetracycline Antibiotics and Their Epimers in Liquid Hog Manure Using Ultra Performance Liquid Chromatography with UV Detection. Chemosphere, 78, 353-359. http://dx.doi.org/10.1016/j.chemosphere.2009.11.020

[23] Bao, Y., Zhou, Q., Guan, L. and Wang, Y. (2009) Depletion of Chlortetracycline during Composting of Aged and Spiked Manures. Waste Management, 29, 1416-1423. http://dx.doi.org/10.1016/j.wasman.2008.08.022

[24] Zhao, L., Dong, Y.H. and Wang, H. (2010) Residues of Veterinary Antibiotics in Manures from Feedlot Livestock in Eight Provinces of China. Science of the Total Environment, 408, 1069-1075. http://dx.doi.org/10.1016/j.scitotenv.2009.11.014

[25] Ho, Y.B., Zakaria, M.P., Latif, P.A. and Saari, N. (2014) Occurrence of Veterinary Antibiotics and Progesterone in Broiler Manure and Agricultural Soil in Malaysia. Science of the Total Environment, 488-489, 261-267. http://dx.doi.org/10.1016/j.scitotenv.2014.04.109

[26] Shelver, W.L. and Varel, V.H. (2012) Development of a UHPLC-MS/MS Method for the Measurement of Chlortetra- 
cycline Degradation in Swine Manure. Analytical and Bioanalytical Chemistry, 402, 1931-1939. http://dx.doi.org/10.1007/s00216-011-5637-4

[27] Wu, X.F., Wei, Y.S., Zheng, J.X., Zhao, X. and Zhong, W.K. (2011) The Behavior of Tetracyclines and Their Degradation Products during Swine Manure Composting. Bioresource Technology, 102, 5924-5931. http://dx.doi.org/10.1016/j.biortech.2011.03.007

[28] VICH (2004) The European Agency for Evaluation of Medicinal Products: Environmental Impact Assessment for Veterinary Medicinal Products. Phase II Guidance. VICH Topic GL 38 (CVMP/VICH/790/03-Final).

[29] Toth, J.D., Feng, Y. and Dou, Z. (2011) Veterinary Antibiotics at Environmentally Relevant Concentrations Inhibit Soil Iron Reduction and Nitrification. Soil Biology \&Biochemistry, 43, 2470-2472. http://dx.doi.org/10.1016/j.soilbio.2011.09.004

[30] Hou, J., Wan, W., Mao, D., Wang, C., Mu, Q., Qin, S. and Luo, Y. (2015) Occurrence and Distribution of Sulphonamides, Tetracyclines, Quinolones, Macrolides and Nitrofurans in Livestock Manure and Amended Soils of Northern China. Environmental Science and Pollution Research, 22, 4545-4554. http://dx.doi.org/10.1007/s11356-014-3632-y

[31] Halling-Sorensen, B., Jacobsen, A.M., Sengelov, G., Vaclavik, E. and Ingerslev, F. (2005) Dissipation and Effects of Chlortetracycline and Ttylosin in Two Agricultural Soil: A Field-Scale Study in Southern Denmark. Environmental Toxicology and Chemistry, 24, 804-810. http://dx.doi.org/10.1897/03-576.1

[32] Sarmah, A.K., Meyer, M.T. and Boxal, A.B. (2006) A Global Perspective on the Use, Sales, Exposure Pathways, Occurrence, Fate and Effects of Veterinary Antibiotics (VAs) in the Environment. Chemosphere, 65, 725-759. http://dx.doi.org/10.1016/j.chemosphere.2006.03.026

[33] Teixido, M., Granados, M., Prat, M.D. and Beltrán, J.L. (2012) Sorption of Tetracyclines onto Natural Soils: Data Analysis and Prediction. Environmental Science Pollution Research, 19, 3087-3095. http://dx.doi.org/10.1007/s11356-012-0954-5

[34] Szatmári, I., Barcza, T., Körmöczy, P.S. and Laczay, P. (2012) Ecotoxicological Assessment of Doxycycline in Soil. Journal of Environmental Science and Health, Part B, 47, 129-135. http://dx.doi.org/10.1080/03601234.2012.624476

[35] Szakmar, K., Reichart, O., Szatmári, I., Erdosi, O., Szili, Z., Laszlo, N., Kormoczy, P.S. and Laczay, P. (2014) In-Vitro Study on the Effect of Doxycycline on the Microbial Activity of Soil Determined by Redox-Potential Measuring System. Acta Microbiologica et Immunologica Hungarica, 61, 317-328.

[36] Liu, F., Wu, J., Ying, G., Luo, Z. and Feng, K. (2012) Changes in Functional Diversity of Soil Microbial Community with Addition of Antibiotics Sulfamethoxazole and Chlortetracycline. Applied Microbiology and Biotechnology, 95, 1515-1623. http://dx.doi.org/10.1007/s00253-011-3831-0

[37] Liu, F., Ying, G.G., Tao, R., Zhao, J.L., Yang, J.F. and Zhao, L.F. (2009) Effects of Six Selected Antibiotics on Plant Growth and Soil Microbial and Enzymatic Activities. Environmental Pollution, 157, 1636-1642. http://dx.doi.org/10.1016/j.envpol.2008.12.021

[38] Wen, B., Liu, Y., Wang, P., Wu, T., Zhang, S., Shan, X. and Lu, J. (2012) Toxic Effects of Chlortetracycline on Maize Growth, Reactive Species Generation and the Antioxidant Response. Journal of Environmental Science, 24, 1099-1105. http://dx.doi.org/10.1016/S1001-0742(11)60901-7

[39] Xie, X., Zhou, Q., He, Z. and Bao, Y. (2010) Physiological and Potential Genetic Toxicity of Chlortetracycline as an Emerging Pollutant in Wheat (Triticum aestivum L.). Environmental Toxicology and Chemistry, 29, 922-928. http://dx.doi.org/10.1002/etc.79

[40] Chen, W., Liu, W., Pan, N., Jiao, W. and Wang, M. (2013) Oxytetracycline on Functions and Structure of Soil Microbial Community. Journal of Soil Science and Plant Nutrition, 13, 967-975. http://dx.doi.org/10.4067/s0718-95162013005000076

[41] An, J., Zhou, Q.X. and Liu, W.T. (2009) Ecotoxicological Effects of Oxytetracycline on Wheat (Triticum aestivum) Based on Seed Germination and Seedling Development. Environmental Science, 30, 3022-3027.

[42] Baguer, A.J., Jensen, J. and Krogh, P.H. (2000) Effects of the Antibiotics Oxytetracycline and Tylosin on Soil Fauna. Chemosphere, 40, 751-757. http://dx.doi.org/10.1016/S0045-6535(99)00449-X

[43] Pino, M.R., Val, J., Mainar, A.M., Zuriaga, E., Español, C. and Langa, E. (2015) Acute Toxicological Effects on the Earthworm Eisenia fetida of 18 Common Pharmaceuticals in Artificial Soil. Science of the Total Environment, 518-519, 225-237. http://dx.doi.org/10.1016/j.scitotenv.2015.02.080

[44] Lin, D., Zhou, Q., Xu, Y., Chen, C. and Li, Y. (2012) Physiological and Molecular Responses of the Earthworm (Eisenia fetida) to Soil Chlortetracycline Contamination. Environmental Pollution, 171, 46-51. http://dx.doi.org/10.1016/j.envpol.2012.07.020

[45] Popova, I.E., Bair, D.A., Tate, K.W. and Parikh, S.J. (2013) Sorption, Leaching, and Surface Runoff of Beef Cattle Veterinary Pharmaceuticals under Simulated Irrigated Pasture Conditions. Journal of Environmental Quality, 42, 11671175. http://dx.doi.org/10.2134/jeq2013.01.0012 
[46] Liu, A., Fong, A., Becket, E., Yuang, J., Tamae, C., Medarno, L., et al. (2011) Selective Advantage of Resistant Strains at Trace Levels of Antibiotics: A Simple and Ultrasensitive Color Test for Detection of Antibiotics and Genotoxic Agents. Antimicrobial Agents and Chemotherapy, 55, 1204-1210. http://dx.doi.org/10.1128/AAC.01182-10

[47] Sandegren, L. (2014) Selection of Antibiotic Resistance at Very Low Antibiotic Concentrations. Upsala Journal of Medical Science, 119, 103-107. http://dx.doi.org/10.3109/03009734.2014.904457 